\title{
The quality of assessment visits in community nursing
}

\author{
Ada Kerkstra PhD \\ Co-ordinator of Community Nursing Research \\ and Frank Beemster MSc \\ Research Fellow, Netherlands Institute of Primary Health Care, Utrecht, The Netherlands
}

KERKSTRA A \& BEEMSTER F (1994) Joumal of Advanced Nursing 19, 1205-1211

The quality of assessment visits in community nursing

The aim of this study was the measurement of the quality of assessment visits of community nurses in The Netherlands Process critena were denved for the quality of the assessment visits from the quality standards of community nursing care established by Appelman et al Over a period of 8 weeks, a representative sample of 108 community nurses and 49 community nursing auxilianes at 47 different locations paid a total number of 433 assessment visits The nursing activities were recorded for each visit The results suggested that most assessment visits (88\%) were pard by community nurses During the assessment visits, community nurses more often paid attention to questions and expectations of the patient than nursing auxiliaries did Furthermore, the quality of taking case histories in the actual practice of assessment appeared to be high in general However, nearly half of the nurses did not enquire whether the patient received care from other health care professionals The drafting of the care plan was, on average, of a lesser quality In particular, the re-assessment of patients was not systematically planned

\section{INTRODUCTION}

Paying assessment visits to patients upon admission to community nursing services is an important task, for community nurses Durng these visits patients are interviewed to assess what kind of nursing care is needed by the patient, and to assess how often patients need care As a result, a care plan is drawn up with the patient, which contains a nursing diagnosis and planned nursing interventions, including the time frames for home visits

In most industrialized countries, assessment visits are done by graduate-level community nurses The decision as to who is going to provide the care (a community Correspondence $\operatorname{Dr}$ A Kerkstra, Netherlands Institute of Primary Health Care (NIVEL), PO Box 15683500 BN Utrecht, The Netherlands nurse or a nursing auxiliary) is also made by the community nurse (Verhel] \& Kerkstra 1992) In Canada, however, assessment for community nursing is made by a home care co-ordinator, who is almost always a nurse and often hospital-based Being hospital-based does not mean that only patients from the hospital are referred, patients may be referred from home as well it is also the community nurse's job to determine the frequency of visits and when they should be evaluated However, a community nurse can challenge the home care coordinator's decision on the basis of his or her own assessment The great influence of the home care coordinator is considered by some people to erode the nurses' autonomy (Pringle 1989) 
In The Netherlands, community nursing services are mainly provided by the Regional Cross Associations At this moment a major re-organization is taking place in 1990 the umbrella organizations for community nursing (National Cross Association) and for home help services (Central Council for Home Help Services) were merged into the National Association for Home Care During the next 5 years, this integration of services is also to take place at the local level, at which the care is delivered The Minustry of Health expects that this integration will increase the efficiency of home care and will avord unnecessary overlap between community nursing and home help services (Ministerie van Welzıjn et al 1990) Many of the new home care organizations intend to combine the assessment of patient need for home help and nursing care within the framework of this integration process (Jansen \& Kerkstra 1993) Furthermore, some people propose that the assessment should be carned out by an independent person, who is not involved in direct patient care and who need not necessarily to be a nurse (Schuppers et al 1990, Slingerland \& van Amelsvoort 1991) For instance, the assessment could also be done by a manager of the home help services The idea behind this is, that this will make the assessment procedure more objective and of a higher quality The health insurance companies in particular are demanding more standardized and objective assessment methods in home care However, other people disagree with thus, because they consider the assessment procedure as an essential first phase in the nursing process (Bujssen 1992) In view of this debate, it would seem important to investigate the quality of the assessment visits of community nurses

\section{Quality of care}

The concept of 'quality of care' is complex and has many different aspects Watertight definitions of quality are elusive In many research projects into quality assessment, the following general definition of quality of nursing is used

Quality of nursing care is defined as the degree of discrepancy between the agreed expectations about the level of nursing care and the current level of nursing practice

(Redfern \& Norman 1990)

The most commonly used model was proposed by Donabedian (1968, 1980), who looked at structure, process and outcome of care Structure refers to the organization providing community nursing services Characteristics of structure include staffing patterns, programmes, finances and facilities Process refers to the vanous aspects of nursing care provided to patients And finally, outcomes are the results of community nursing services in terms of a patient's knowledge, health and physical functioning abilities In addition, aspects of patient satisfaction are considered as outcome measures

Quality of nursing care can be assessed by measuring the degree of discrepancy between criteria (denved from standards) and the current level of nursing practice Standards are defined as the agreed expectations regarding the level of nursing care According to Kitson \& Kendall (1986) standards can be subdivided into 'criteria' or discrete items of practice which are observable and measurable

In 1989, The Netherlands quality standards were established for community nursing care by Appelman et al (1989) These standards were developed by consensus among identified experts in community nursing and mainly concern the process of community nursing care Standards for the assessment visits of community nurses are included

\section{THE STUDY}

The Netherlands Institute of Primary Health Care (NIVEL) has investigated the nature of care delivered by community nurses and nursing auxilianes in a national representative sample (Vorst-Thyssen et al 1990) With the help of these data, process criteria were denved from the established standards by Appelman et al (1989), in order to measure the quality of assessment visits in community nursing The study presented here concentrated on the quality of the process of the assessment visits Only one structural aspect of the assessment visits was taken into account, that is the requirement stated in the Profile of the Nursing Profession' in The Netherlands (Nationale Raad voor de Volksgezondheid 1988) to allow only graduate-level nurses to pay assessment visits In community nursing, community nurses are considered as graduate-level nurses and nursing auxilanes are considered as non-graduate-level nurses Finally, in this study no outcome measures were taken into account, because no data were avalable in the NIVEL study regarding the outcome of the assessment visits, and also because no standards on this subject were avallable

\section{METHOD}

This investigation concerned a secondary analysis of data gathered in a national representative study of the activities of nurses workang in the community (Vorst-Thissen et al 1990) Thus means that the data were not collected 
with the aim of measuring quality of care It also implies that the participating community nurses and nursing auxilianes did not know that their actual practice would be compared with the quality standards

The onginal data were gathered in a representative national sample of 108 community nurses and 49 nursing auxuliaries at 47 different locations in The Netherlands During a period of 8 weeks they recorded all assessment visits paid to patients on admission to community nursing services and the activities undertaken during these visits They also kept records of the time spent on these assessment visits They recorded their activities on a diary sheet which was developed and tested for reliability and validity in a pilot study (Kerkstra \& de Wit 1988) A total number of 433 patients recerved an assessment visit during the 8-week penod

\section{Standards and criterra}

The quality of the assessment visits was measured as follows As mentioned above, one structural aspect of the quality of the assessment visits was considered in this study This structural aspect was denved from the Profile of the Nursing Profession' in The Netherlands (Nationale Raad voor de Volksgezondherd 1988) Furthermore, the standards for community nursing care established by Appelman et al (1989) served as a starting point for this study into the quality of the nursing activities during assessment visits

These standards concern three main aspects of the process during an assessment visit

1 Paying attention to questions of the patient and to his or her expectations of community nursing

2 Taking a case history (collection of information)

3 Drawing up the nursing care plan

The first aspect concerns a fundamental attitude of the community nurse she or he has to consider the suggestions of the patients The second aspect concerns the collection of data needed to formulate the nursing diagnosis And, thirdly, Appelman et al (1989) have established standards for the nursing activities needed to make the nursing care plan An overview of the standards formulated and the denved criteria used in this study to measure the quality of the assessment visits is presented in Table 1

\section{RESULTS}

\section{Structural criteria}

According to the criterion formulated, only community nurses are allowed to pay assessment visits However, the results show that $12 \%$ of the assessment visits were paid by nursing auxilianies Nevertheless, carrying out an assessment procedure does not seem to be a regular task for nursing auxilianes, since nearly all community nurses (98 out of 108) paid assessment visits, whereas only a minonty of nursing auxilianes did (only 21 out of 49) Furthermore, on average, community nurses paid three to four assessment visits during 8 weeks and nursing auxuliaries only one

Consequently, in the actual practice of community nursing, assessment procedures may be considered as a task of community nurses, and $88 \%$ of the assessment visits investigated met the criterion formulated

\section{Process criteria}

Paying attention to questions and expectations

The critenon formulated is met when the community nurse has discussed the expectations of community nursing with the patient (or her or his family)

Table 2 shows that this criterion was met during $88 \%$ of the assessment visits It also shows that community nurses more often paid attention to the patient's expectations than nursing auxiliaries did

\section{Taking a case history}

The second main aspect of the assessment visits concerned taking case histories First, the community nurse has to collect general data about the patient, like personal details (name, date of birth, sex, ethnicity), living situation and whether or not the patient is receiving care from other health care professionals

The results show that in every assessment visit these criterna were met, with the exception of the last one In only $57 \%$ of the assessment visits did community nurses and nursing auxiliaries ask whether the patient was also receiving care from other professionals, ie from the general practitioner, a social worker or from home help services This means that the co-ordination of care leaves much to be desired, since nearly $50 \%$ of the nurses were not informed about the patient's contacts with other care providers

Second, the community nurse has to collect information on the health status of the patient and the nursing care situations, ie information regarding the physical, psycho-social and housing conditions of the patient Information gathered on the physical condition of the patient involves her or his medical history and the diagnosis includes her or his illness, the history of the lliness and whether he or she has been admitted 
Table 1 Standards and criteria for the quality of assessment visits by community nurses

\section{Structure}

Standard. Assessment procedures are reserved to graduate-level nurses

Cnterion: Assessment visits are only pard by community nurses

\section{Process}

Paying attention to patient's questions and to her or his expectations of communty nursing

Standard: The community nurse has to pay attention to questions of patients and her or his family regarding disorders and problems, and to their expectations for community nursing

Criterion: The community nurse has discussed during the assessment visit the patient's and her or his famuly's

Taking a case history expectations for community nursing

Standard- After the assessment visit the community nurse has to have the general data on the patient

Cnteria: After the assessment visit the community nurse has been informed about

(a) the personal detals (name, date of burth, sex, ethrucity),

(b) living situation,

(c) whether or not the patient is receiving care from other health care professionals

Standard- During the assessment visit the community nurse has to collect data concerning the health status of the patient and the nursing care situation

Criteria: Durng the assessment visit the community nurse collects data concerning

(a) physical conditions of the patient,

(1) medical health history and diagnosis,

(ii) physical disorders or handicaps,

(iii) use of medicnes,

(iv) diet,

(v) self-care options,

(b) psycho-social conditions,

(1) mental constitution,

(ii) the expectations and the patient's knowledge of the illness,

(iii) possibilities of receiving informal care from the family,

(c) housing conditions

Drawing up the nursing care plan

Standard: Dunng the assessment visit the community nurse has to determine with the patient the need for nursing care the communuty nurse summanzes the nature, the ongin and consequences of the disorders and problems, and from this she or he determines the need for nursing care The community nurse has to venify with the patient whether the summary and conclusions are correct

Criterion. During the assessment visit the community nurse makes the nursing diagnosis with the patient

Standard: After the assessment visit, the patient has been informed about the general procedures and the care supplied by the Regional Cross Association with reference to the nursing diagnosis, the community nurse has to develop the plan of nursing care with the patient

Criteria During the assessment visit the community nurse discusses with the patient

(a) the general procedures and the care supplied by the Regional Cross Association,

(b) the goal of the nursing care to be provided,

(c) the planning of the nursing interventions (nature of care, frequency and penod),

(d) the contribution of self-care,

(e) the contribution of informal care,

(f) planning of an evaluation date

to the hospital or not, etc The physical condition also includes the physical disorders of the patient as well as her or his perception of the disorders The criterion of the 'use of medicines' is met when the community nurse has asked whether the patient is using medicines and if so what form The same applies to the critenion of diet Finally, the critenon of 'self-care options' is met when the community nurse has discussed the self-care deficits and the patient's level of mobility 
Table 2 Attention pad to expectations of the patient or her or his family of community nursing during the assessment visits $(n=433)$

\begin{tabular}{ll}
\hline Community nurses & $89 \%$ \\
Nursing auxularies & $79 \%$ \\
Total & $88 \%$ \\
\hline
\end{tabular}

Table 3 Overview of the extent to which nurses have been collecting data concerning the physical condition of the patient durng the assessment visits

\begin{tabular}{|c|c|c|c|}
\hline Cntena & $\begin{array}{l}\% \\
\text { total } \\
(n=433)\end{array}$ & $\begin{array}{l}\% \\
\text { community } \\
\text { nurses } \\
(n=381)\end{array}$ & $\begin{array}{l}\% \\
\text { nursing } \\
\text { auxulianes } \\
(n=52)\end{array}$ \\
\hline
\end{tabular}

Medical health history

and diagnosis

Physical disorders

\section{6}

97

81

50

86

$\begin{array}{ll}86 & 86 \\ 97 & 98 \\ 80 & 92^{*} \\ 48 & 67^{* *} \\ 85 & 92\end{array}$

$x^{2}=49 \quad P=0.03$

$* x^{2}=6.8 P=0.01$

From the results, it appeared that information concerning the physical condition of the patient was collected in most of the assessment visits (Table 3) The medical health history and diagnosis of the patient, the physical disorders or handicaps, the use of medicines and the possibilities of self-care were assessed particularly frequently during the visits What was most striking, was that in half of the cases the nurse did not ask whether the patient had to follow a diet or not Accordingly, it can be concluded that this criterion was met in only $50 \%$ of the assessment visits However, nursing auxulianes collected data on the diet of the patient more often when compared with community nurses

As regards to the collection of information about the psycho-social conditions of the patient, the results are shown in Table 4

In three-quarters of the visits the nurses discussed the mental constitution of the patient However, it is possible that the observed mental condition of the patient did not always give nse to a discussion of it with the patient The option of informal care by the tamily was also discussed in more than $80 \%$ of the cases
Table 4 Overview of the extent to which nurses have been collectung data concerning the psycho-social conditions of the patient during the assessment visits

\begin{tabular}{llll}
\hline & $\begin{array}{l}\% \\
\text { total } \\
(n=433)\end{array}$ & $\begin{array}{l}\% \\
\text { community } \\
\text { nurses } \\
(n=381)\end{array}$ & $\begin{array}{l}\% \\
\text { nursing } \\
\text { auxilianes } \\
(n=52)\end{array}$ \\
\hline $\begin{array}{l}\text { Citeria } \\
\begin{array}{l}\text { Expental constitution } \\
\text { patient's knowledge } \\
\text { of the lllness }\end{array}\end{array}$ & 75 & 74 & 79 \\
\begin{tabular}{l} 
Informal care options \\
\hline
\end{tabular} & 57 & 56 & 63 \\
\hline
\end{tabular}

Finally, it was striking that the patient's expectations and knowledge of the illness were assessed in only $57 \%$ of the cases, whereas the physical condition of the patient was nearly always assessed This difference cannot be explained by the absence of a physical disorder or handicap, because $93 \%$ of the patients had a medical diagnosis

The housing conditions can be explicitly discussed by the community nurse with the patient in connection with her or his disorder(s) or handicap(s) Another option is that the nurse observes that the housing conditions do not meet the needs of the patient

This criterion was met in only $57 \%$ of the assessment visits In this regard, there were no differences between community nurses and nursing auxilianes This low figure could possibly be explained by the absence of a reason for discussing housing conditions with the patient For instance, when the housing conditions meet the patient's needs, or when the patient's situation gives no rise to such problems

\section{Drawing up the nursing care plan}

The thurd main aspect of the assessment visit concerns the activities of the community nurse within the nursing care plan The first step is to make the nursing dragnosis, i e the community nurse summarizes the nature, the ongin and consequences of the disorders and problems, and from this she or he determines the need for nursing care In addition, she or he has to venfy with the patient whether the summary and conclusions are correct This criterion was met in nearly $75 \%$ of the assessment visits Community nurses more often made nursing diagnoses (in $76 \%$ of the assessment visits) than nursing auxilianes $(67 \%)$ 
Table 5 Overview of the extent to which the critena concerning the formulation of a care plan are met durng the assessment visits

\begin{tabular}{|c|c|c|c|}
\hline Cnterna & $\begin{array}{l}\% \\
\text { total } \\
(n=433)\end{array}$ & $\begin{array}{l}\% \\
\text { communty } \\
\text { nurses } \\
(n=381)\end{array}$ & $\begin{array}{l}\% \\
\text { nursing } \\
\text { auxuliaries } \\
(n=52)\end{array}$ \\
\hline General information & 59 & 60 & 54 \\
\hline $\begin{array}{l}\text { Goal of nursing care } \\
\text { Planning of nursing }\end{array}$ & 69 & 70 & 62 \\
\hline interventions & 68 & 69 & 63 \\
\hline Self-care & 67 & 65 & $83^{*}$ \\
\hline Informal care & 63 & 62 & 71 \\
\hline Evaluation date & 30 & 28 & $42^{* *}$ \\
\hline
\end{tabular}

$\chi^{2}=68 \quad P=001$

${ }^{*} \chi^{2}=42 \quad P=004$

Different critena have been denved from the second standard for the quality of the nursing care plan (Table 1) The criterion of 'giving information regarding the Regional Cross Association' is met when the communty nurse has informed the patient about the general procedures of the Regional Cross Association The community nurse has to explain what specific goals can be reached for the patient as regards the goals of nursing care In respect of the planning of the nursing interventions, the community nurse has to explain how to reach the goals Within the context, possible contributions of the patient and her or his family have to be discussed Finally, an evaluation date has to be planned That is to say, durng the evaluation the efficacy of the nursing plan is examined the patient is re-assessed, the results are analysed, and the plan is modified as needed

As Table 5 shows, this last criterion would appear to be one of the weaknesses of the assessment visit The criterion of 'planning an evaluation date' was met in only $30 \%$ of the cases In general, the criteria for the nursing care plan were met to a lesser extent than the criteria for taking case histories

\section{CONCLUSIONS}

This study measured the quality of the assessment visits in the daily practice of community nursing against the standards of community nursing care in The Netherlands developed by Appelman et al (1989) As regards the structural critenion investigated in respect of the quality of the assessment visits, it can be concluded that in actual community nursing practice, paying assessment visits is manly performed by graduate-level nurses

In respect of the process criteria investigated on the quality of the nursing activities during the assessment visits, the following conclusions can be drawn First, the results showed that in $\mathbf{8 8 \%}$ of the assessment visits nurses pard attention to questions of the patient and to her or his expectations of community nursing Community nurses showed this behaviour more often than nursing auxilianes This means that the nurses were open to suggestions of the patients and this also arded in removing possible sources of misunderstanding

Second, it can be concluded that the quality of case histones in the actual practice can in general be considered as high During most assessment visits relevant information was collected systematically However, one important part of the case histones left much to be desired nearly half of the nurses failed to ask whether the patient had received care from other health care professionals This means that in these cases the care provided by the community nurse cannot be coordinated with the help the patient has received from other professionals, such as the general practitioner, home help services or physiotherapists

Third, it can be concluded that the final part of the process during the assessment visit, that is the making of the care plan, was on average of a lesser quality, particularly in the evaluation of the nursing care In only $30 \%$ of the assessment visits was an evaluation date planned This means that in actual practice the re-assessment of the patients was not planned systematically

Finally, the results show that the quality of the assessment visits (12\%) pard by nursing auxilianes was about the same as the assessment visits paid by communty nurses On some criteria, for instance gathering information about the use of medicines or diet, they even scored better A possible explanation could be that because paying assessment visits is not a regular activity of nursing auxilaries, they prepare themselves very well when they have to do the assessment

\section{High quality}

In summary, it can be concluded that in the actual practice of community nursing in The Netherlands many aspects of the assessment visit process appear to be of a high quality However, if the community nurses want to retain this important co-ordinating task in the future, then they will have to pay more attention to the planning of systematic re-assessment of the patients and to coordination with care providers Because of the increasing 
demand for nursing care at home and because of the integration with the home help services, these topics will become more important in the near future

Finally, one comment on this investigation in this study the quality of outcome aspects were not taken into account For instance, it was not investigated whether, on the basis of the assessment visits, the patients received the care they needed from a nurse of the night level of expertise For the overall picture of the quality of the assessment visits in community nursing, it would be necessary to measure outcome too However, the few avallable tools either measure process or outcome of communty nursing care, but not in two in conjunction (Redfern \& Norman 1990, Harvey 1991, Toms 1992) Consequently, the development of research instruments that combine the measurement of the quality of both the process and outcome of community nursing care is to be recommended

\section{References}

Appelman A, Ligtenberg $\mathrm{H}$, van Bergen B \& Hollands $\mathrm{L}$ (1989) Ontwikkeling van Kwalitetsstandaarden ooor de Wijkoerpleging De Tydstroom, Lochem, The Netherlands

Buyssen H (1992) Loskoppelen betekent onbekwaamheidsverklarng wijkverpleegkundigen Maatschappelyke Gezondheidszorg 20(7), 12-15

Donabedian A (1986) Promoting quality through evaluating the process of patient care Medical Care 4(3), 181-202

Donebedian A (1980) Explorations in Quality Assessment and Monitonng Volume I The Defintion of Quality and Approaches to ts Assessment Health Administration Press, Ann Arbor, Michigan

Harvey G (1991) An evaluation of approaches to assessing the quality of nursing care using (predetermined) quality assurance tools Joumal of Adoanced Nursing 16, 277-286
Jansen P G M \& Kerkstra A (1993) Functiedifferentiatie binnen de Thuiszorg NIVEL, Utrecht

Kerkstra A \& de Wit A.MGJ (1988) Het werk van de wijkverpleging gemeten instrumentontwikkeling Verpleegkunde 3, 140-152

Kitson AL \& Kendall H (1986) Quality assurance Nursing Times 82(35), 29-31

Ministerie van Welzın, Volksgezondheld \& Cultuur (1990) Van Samenwerken naar Samengaan Gezinsverzorging en Kruiswerk naar een Geintegreerd Aanbod in de Thuiszorg Minusterie van Welzijn, Volksgezondheid \& Cultuur, Rujswık, The Netherlands

Nationale Raad voor de Volksgezondheid (1988) Verpleegkundig Beroepsprofiel Nationale Raad voor de Volksgezondherd, Zoetermeer, The Netherlands

Pringle DM (1989) Community Nursing in Canada In Communty Nursing (Kerkstra A \& Verhel] R A eds) Proceedings of the International Conference on Community Nursing, 16-17 March, NIVEL, Utrecht, pp 70-81

Redfern SJ \& Norman IJ (1990) Measuring the quality of nursing care a consideration of different approaches Journal of Adoanced Nursing 15, 1260-1271

Schuppers A, van Amelsfoort F \& Rutten H (1990) Tussen Vraag en aanbod Intake, Indicatiestelling en Zorgtoewizing $b_{i j}$ Gezinsoerzorging en Wijkoerpleging NIZW, Utrecht

Slingerland P \& van Amelsfoort F (1991) Indiceren, een vak apart of een apart vak? Maatschappelijke Gezondhetdszorg 19(9), 4-7

Toms EC (1992) Evaluating the quality of patient care in district nursing Journal of Adoanced Nursing 17, 14891495

Verhei] RA \& Kerkstra, A (1992) International Comparatwe Study of Community Nursing Avebury, Aldershot, Hampshire

Vorst-Thussen T ML, van den Brink-Mumen A \& Kerkstra A (1990) Het Werk van Wijkverpleegkundigen en Wijkziekenverzorgenden in Nederland NIVEL, Utrecht 
This document is a scanned copy of a printed document. No warranty is given about the accuracy of the copy. Users should refer to the original published version of the material. 